\title{
DISCRIMINATION OF RESERVOIR FLUID CONTACTS USING COMPRESSIONAL AND SHEAR WAVE VELOCITY
}

RASAQ BELLO AND YEMI SIKIRU ONIFADE

(Received 17 June 2016; Revision Accepted 8 August 2016)

\begin{abstract}
Improved fluid detection and lithology discrimination using rock properties and attributes cross plots have been attempted using well log data in an Onshore Niger Delta field. Rock properties and attributes were extracted using empirical rock physics models on well logs and used to validate their potentials as pore fluid discriminants. These rock properties and attributes were cross plotted for the primary purpose of investigating their sensitivity to fluid and lithology in cross plot space. $V_{p}$ and $V_{s}$ logs were derived from the inverse of interval transit times of sonic and dipole shear logs respectively. $V_{p} / V_{s}$ ratio, acoustic impedance and porosity were derived from $V_{p}, V_{s}$ and density logs using appropriate relations. The identified depth of reservoir of interest (A2) for Well A and B ranges from $5842 \mathrm{ft}$ to $5964 \mathrm{ft}$ and $5795 \mathrm{ft}$ to $5936 \mathrm{ft}$ respectively. The properties cross plotted comprise $\mathrm{V}_{\mathrm{p}} v s \mathrm{~V}_{\mathrm{s}}, \mathrm{V}_{\mathrm{p}} / \mathrm{V}_{\mathrm{s}} v s \mathrm{l}_{\mathrm{p}}, \mathrm{V}_{\mathrm{p}} / \mathrm{V}_{\mathrm{s}} \mathrm{vs}$ Porosity, $\mathrm{V}_{\mathrm{p}} / \mathrm{V}_{\mathrm{s}} v s$ Density and $V_{p} v s$ Density. $V_{p} v s$ Density cross plot revealed that the reservoir consists of sand lithology with intercalated shale. $V_{p} v s V_{s}$ shows a linear relationship and does not discriminate fluid in the reservoir. $V_{p} / V_{s}$ ratio $v s l_{p}$ distinguish $\mathrm{A} 2$ into hydrocarbon, brine and shale zones. $\mathrm{V}_{\mathrm{p}} / \mathrm{V}_{\mathrm{s}}$ ratio vs density and porosity crossplots distinguishes the $A 2$ into gas, oil, brine and shale zones. The analysis validates the fact that $V_{p} / V_{s}$ ratio and their combinations cross plots are more sensitive and robust for fluid discrimination. It also reveals that the ratio of $V_{p} / V_{s}$ is more sensitive to change of fluid type than the use of $\mathrm{V}_{\mathrm{p}}$ or $\mathrm{V}_{\mathrm{s}}$ separately.
\end{abstract}

KEYWORDS: Crossplot, Reservoir, Porosity, Acoustic Impedance, Density

\section{INTRODUCTION}

In reservoir characterization, the prediction of elastic properties such as density, P- and S-wave velocities, as well as their relations to rock properties such as lithology, porosity or fluid content, is of critical importance. This analysis also constitutes a crucial step for different applications such as seismic modeling, amplitude versus offset (AVO) variations. These techniques are used to alter well curve to reflect a change of fluid type. It generates fluid scenarios of different pore fills, which might explain an observed amplitude variation with offset (AVO) anomaly (Veeken and Rauch, 2006).

In petrophysical evaluations, compressional wave velocity data are very useful in identifying lithology, porosity and pore fluids. Shear wave velocity data are also useful for mineral identification. Velocity is one of the most important petrophysical parameters used in oilfield optimization or other geophysical surveys to easily determine and predict horizons, faults, facies, unconformities, stratigraphic boundaries, geologic structures, fluid contents etc. (Tamunobereton-ari et al., 2010).

Identification of lithology, porosity and pore fluids in a reservoir requires data on $P$-wave transit time. $S$-wave data are also useful for mineral identification and porosity determination. There is evidence that $S$ wave transit time may be useful for fluids identification.
Combining $S$-wave data and $P$-wave data will help in fluid type identification especially gas reservoirs (Hamada, 2004).

The use of $P$-wave and $S$-wave is very helpful in identifying fluids type in porous reservoir rocks. It is found that $P$-wave velocity decreases and $S$-wave velocity increases with the increase of light hydrocarbon in place of brine saturation. This is true within the range of free gas or free hydrocarbon saturation. In this work, the technique of $V p / V s$ was used as fluid identification tool and how the $V p / V s$ cross plot can distinguish between fluids.

Cross plotting appropriate pairs of attributes so that common lithologies and fluid types generally cluster together allows for straightforward interpretation. The off-trend aggregations can then be more elaborately evaluated as potential hydrocarbon indicators (Chopra et al., 2006).

Cross plotting of rock properties from well logs is one very convenient and efficient way to look at two rock properties and their attributes (combination of rock properties) at the same time (Buriank, 2000). It also shows quit decisively which rock properties and their attributes will be helpful to discriminate gas in a particular reservoir. Rock properties are those physical properties of a rock such as P-wave and S-wave velocity, bulk density, porosity, rigidity, that will affect how seismic wave travel through the rock (Dewar, 2001). 
In this work, cross plotting techniques of rock properties (particularly $\mathrm{Vp}$ and $\mathrm{Vs}$ ) has been extracted and used to validate their potential as pore fluid discriminant using logs in an Onshore field.

\subsection{LOCATION/GEOLOGY OF THE STUDY AREA}

The four well logs (Well A, B, C \& D) used in this study are from ' $X$ ' field. It is located in the costal swamp depobelt of Niger Delta (Figure 1). It lies within the concession of Shell Petroleum Development Company of Nigeria. The field is located between located 3ㄴ - 6N and 5-- $8^{\circ} \mathrm{E}$ and situated on the West African continental margin, at the apex of the gulf of Guinea, which formed the site of a triple junction during continental breaking up in the cretaceous age (Whiteman, 1982). The Niger Delta is one of the world's largest tertiary Delta systems and an extremely prolific hydrocarbon province (Reijers et al., 1996). Its present morphology is that of wave dominated delta with a smoothly seaward - convex coastline traversed by distributaries. From apex to coast, the aerial portion stretches more than $300 \mathrm{~km}$ (Reijers et al., 1996), covering an area of $75,000 \mathrm{~km}^{2}$ (Doust and Omatsola, 1990; Tuttle et al., 1999). Below the Gulf of Guinea two enormous lobes protrude a further $250 \mathrm{~km}$ (Doust and Omatsola, 1990; Tuttle et al., 1999) into deep water.

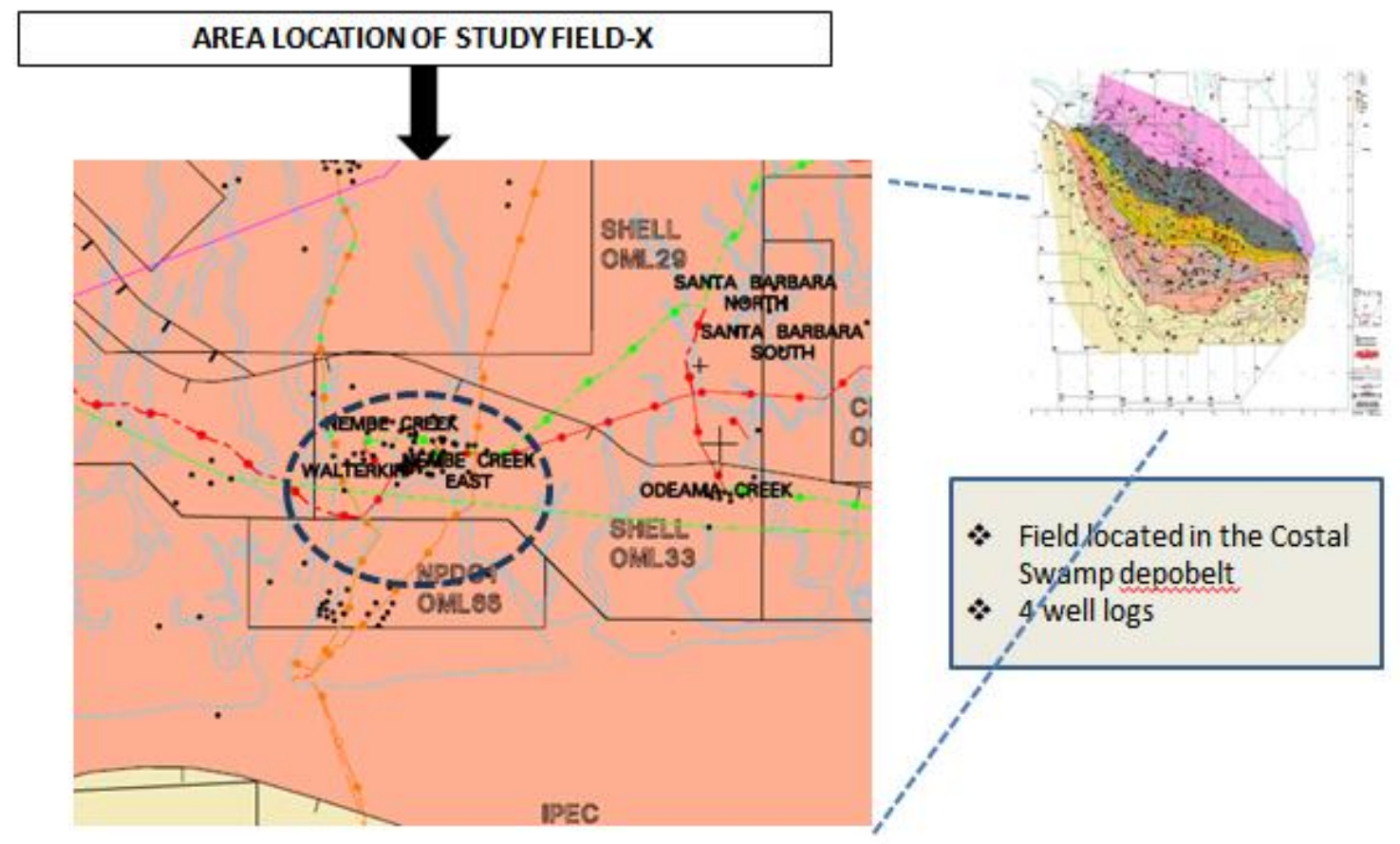

Figure 1: Map of Niger Delta showing the study Area X- FIELD.

\section{$2.0 \quad$ Literature Review}

Numerous studies have shown that the ratio of compressional wave velocity (Vp) to shear wave velocity (Vs) is indicative of lithology. Pickett (1963) was one of the first to suggest using Vp/Vs as a lithologic indicator, by determining $\mathrm{Vp} / \mathrm{Vs}$ values from core measurements from different types of rocks, such as dolomite, limestone and sandstone. The knowledge of velocity at any depth is very important in the recognition of reflectors and refractors with dip or plane horizontal beds (Tamunobereton-ari et al., 2011).

Banik et al., (2010) alleviate the requirement for density by using the correlation of $I_{s}$ or $I_{p}$ and Young's modulus from log data, and using that relationship for computation of Young's modulus. They also demonstrated the determination of Young's modulus from seismic data by way of inversion.

Eastwood and Castagna (1983) studied full waveform sonic logs in Appalachian limestone and observed that shear wave amplitude was attenuated in shale zones, and thus it could be used for lithology
Rafavich et al., (1984) in a detailed laboratory study of velocity relationships with petrographic character in carbonates concluded that the $(\mathrm{Vp} / \mathrm{Vs})$ ratio successfully differentiated limestone and dolomite.

Rock physics approaches have also been used for predicting elastic properties. Greenberg and Castagna (1992) predict Vs using Biot-Gassmann theory under the assumption that $\mathrm{P}$ - and $\mathrm{S}$-wave velocities are related robustly and that nearly linear mixing laws for solid rock constituents are valid.

Xu and White (1996) predict S-wave velocity using a combination of Kuster and Töksoz (1974) theory and the differential effective medium theory, incorporating pore aspect ratios to characterize the compliance of the sand and clay components.

Wang (2000) developed another empirical equation that predicts S-wave velocity using the bulk density of the saturated rock, the pore fluid modulus and the P-wave velocity, allowing for other fluids besides water to fill in the pore space.

Shear waves are slower than compressional 
making converted-wave exploration useful for fluid and lithology discrimination, imaging structure through gas clouds and fracture detection by analysis of shear wave splitting, among other applications (Garotta et al., 2002). The rock properties obtained from sonic and density logs can also be used to construct the reflection coefficients of the various reflectors or geologic boundaries (Henry, 2006). Dabagh et al., (2011) have shown a comparison of $\kappa \rho$ and $\lambda \rho$, and that $\kappa \rho$ comes out as a superior attribute for fluid detection.

\subsection{METHODOLOGY}

The proposed methodology comprised of the following stages: well-log conditioning, attribute generation from log data and crossploting. However, there are other processes that shall be involved.

The proposed workflow for this work is shown in figure 2 .

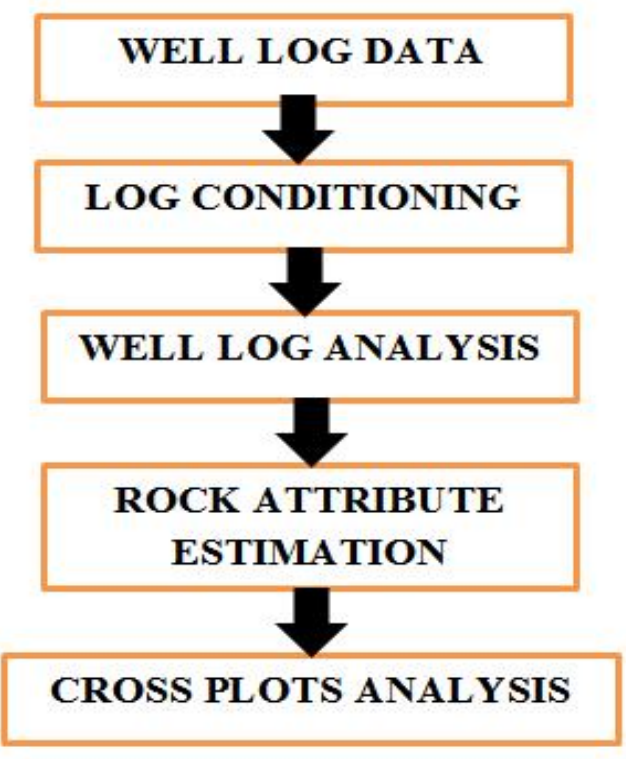

Figure 2: Summarized Workflow showing the proposed methodology

In the end, the results from the four stages shall be analyzed in other to delineate fluids in the reservoir A2000.

The methodologies that shall be employed are described as in the following sections.

\subsection{Well Log Loading and Quality Control}

The well logs, each with a basic petrophysically QC'ed (Quality Checked) log suite, was loaded and compiled in a new project. Also, other data imported included directional survey and well markers. The logs shall be de-spiked, filtered, edited to remove spurious events reduce the scatter in the lithology, fluid and cross plot analyses. The median filter shall be applied iteratively to the logs in order to remove high frequency noise from the sonic log using one or more input logs acquire from the well without increasing the high frequency geologic component of the surface.

\subsection{Well Log Analysis}

The next step will be to evaluate the well logs for petrophysical properties to determine reservoir zones with considerable hydrocarbon saturation. The wells shall be analysed in terms of fluid type, fluid contact and lithology. Hydrocarbon-water-contact (HCWC) analysis and hydrocarbon saturation estimation based on well logging data shall be done too.

\subsubsection{Lithology Discrimination}

The wells shall be analysed for lithology. Gamma ray logs will be used to delineate shale/sand lithologies. High gamma ray value indicates shale lithology.

\subsubsection{Hydrocarbon-Water-Contact (HCWC) Analysis}

Resistivity logs are used to determine OWC and GWC depth in a well bore. Resistivity logs are used to calculate Water saturation (Sw), and if there is a significant decrease in the Sw values, that depth is defined as the fluid contact depth.

\subsection{Well Log Attribute - Cross Plot Analysis}

Cross plots are visual representations of the relationship between two or more variables, and they are used to visually identify or detect anomalies which could be interpreted as the presence of hydrocarbon or other fluids and lithologies. Cross plot analysis are carried out to determine the rock properties / attributes that better discriminate the reservoir (Omudu and Ebeniro, 2007).

The $V_{\mathrm{P}} / V_{\mathrm{S}}$ ratio is a fluid indicator because compressional waves are sensitive to fluid changes, whereas shear waves are not except in the special case of very viscous oil (Han et al., 2007).

Acoustic impedance versus $V_{\mathrm{P}} / V_{\mathrm{S}}$ ratio contrast can show the position of gas-sand, water-sand and shale in a $V_{\mathrm{P}} / V_{\mathrm{S}}$ versus impedance crossplot as shown 


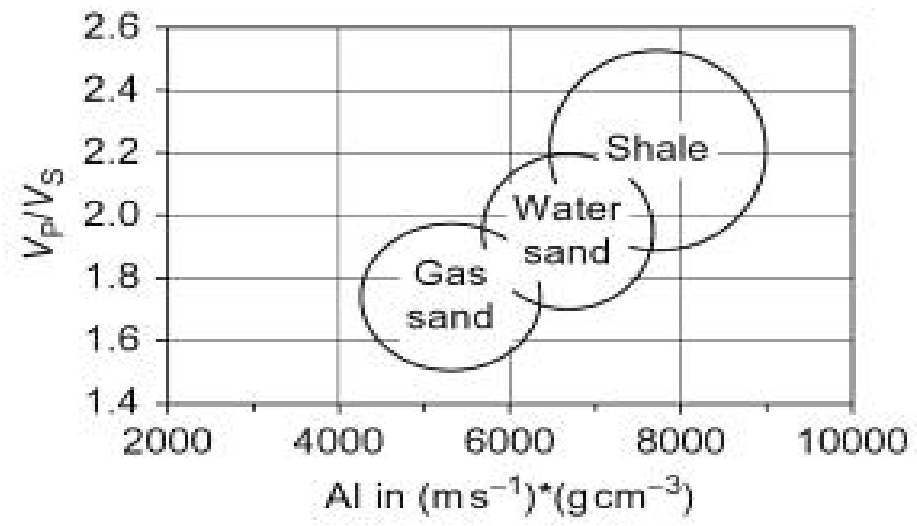

Figure 3: Position of gas sand, water and shale in $\mathrm{Vp} / \mathrm{Vs}$ versus acoustic impedance Al plot

Figure 4 below shows a cross plot based on a figure from Odegaard and Avseth, 2004.
It demonstrates the difference between sand and shale, the change of properties from pore fluid gas to water and the influence of porosity.

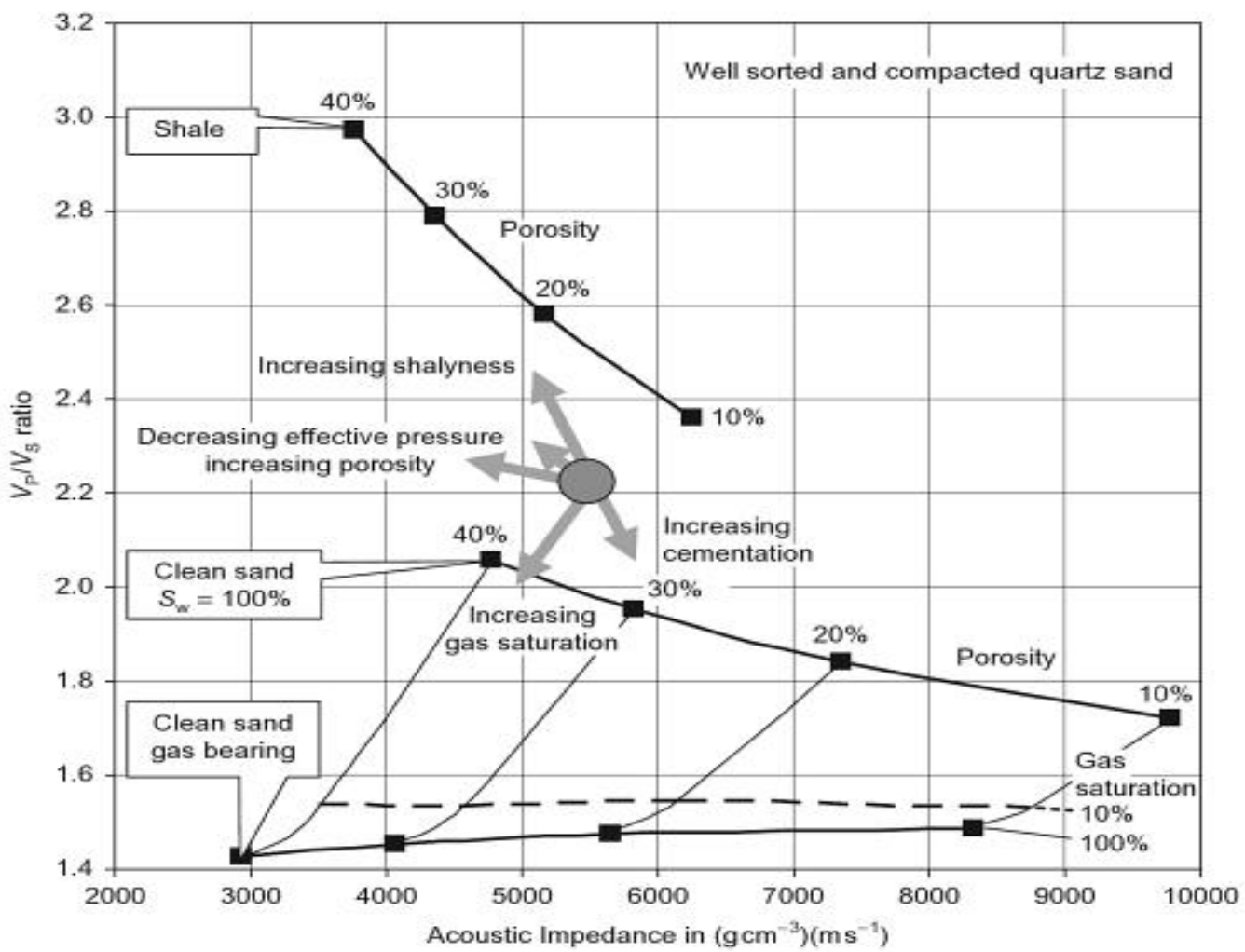

Figure 4: Crossplot $V_{\mathrm{P}} / \mathrm{V}_{\mathrm{S}}$ versus acoustic impedance $\mathrm{Al}$, drawn after a figure 'RPT' from Odegaar and Avseth 2004. The effects of changing reservoir parameters on a point of the crossplot are here shown by arrows.

\subsection{RESULTS AND DISCUSSIONS}

In this section, the results of well log analysis, attribute generation and crossplots analyses are presented. The analysis of the various logs is vital to determine the lithology of the reservoirs and to study the reservoirs of interest. The attributes ( $\mathrm{P}$-impedance and $\mathrm{VpVs}$ ratio) are then generated from $V p, V s$ and density logs. Several crossplots are carried out to see which best well. Our analysis was performed on real field data from onshore Niger Delta.

\subsection{Well Log Analysis}

The logs used for the analysis (Figure 5 and Figure 6) include caliper, gamma ray, porosity, resistivity (LLD), density and $P$-wave for well $A$ and well $B$, respectively. The depth of the reservoir of interest (A2000) ranges 
for well $B$. The wells exhibit a dominantly shale/sand/shale sequence typical of the Niger delta formation. The hydrocarbon-water-contact (HCWC) occurs at a depth of $5866 \mathrm{ft}$ in well $A$ and at $5795 \mathrm{ft}$ (TVD) in well B. The wells were analysed in terms of fluid type and lithology. Shale lithologies were delineated by the high gamma ray value. Regions showing low gamma ray, high resistivity, and low acoustic impedance are mapped as sand lithologies. Sand lithologies showing very low acoustic impedance and high resistivity are regions of high hydrocarbon saturation. However, the unavailability of neutron log and SP log has restrained further discrimination of the wells in terms of their fluid contacts and fluid type.

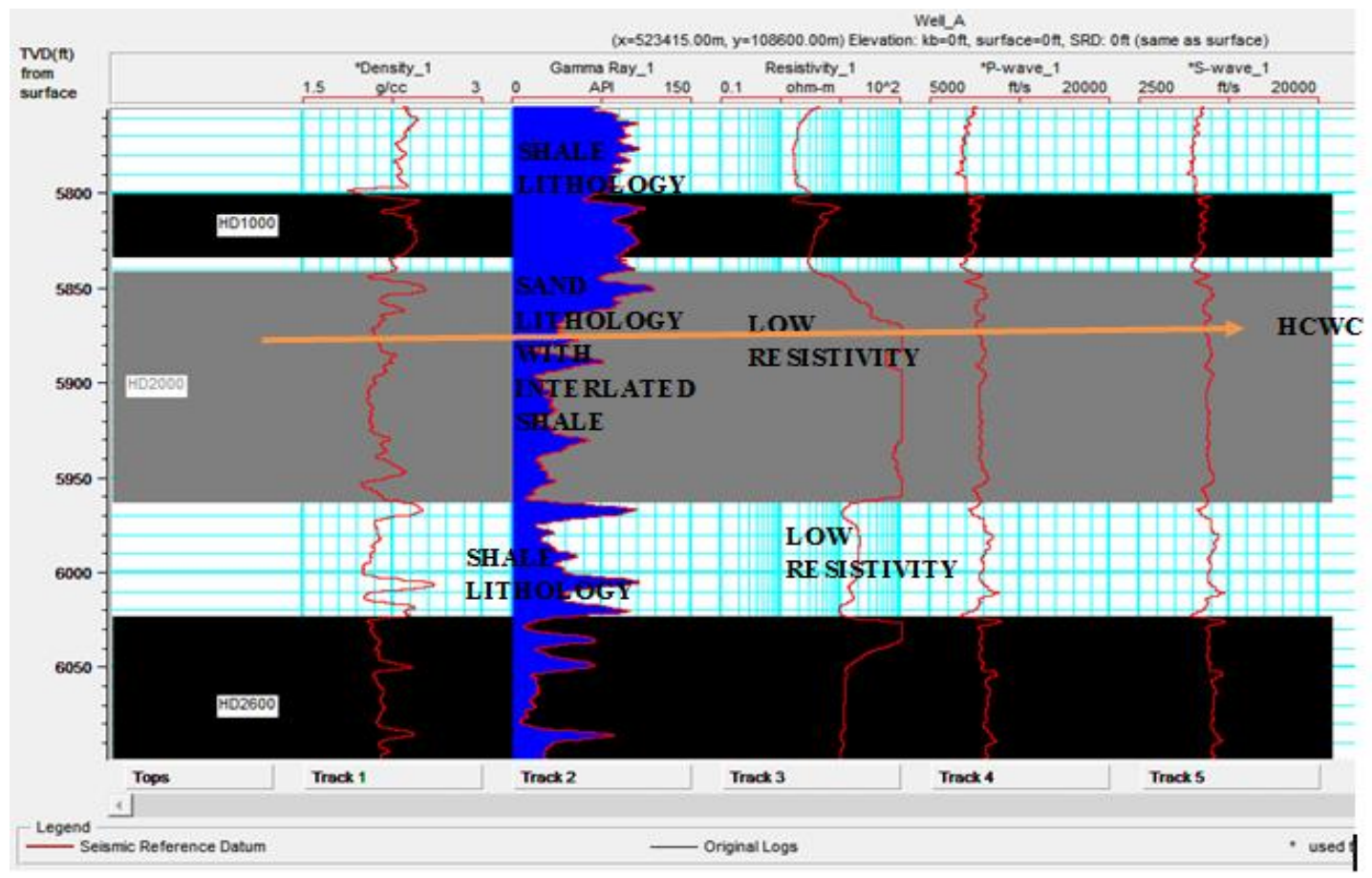

Figure 5: Well A and suite of Logs used in the analysis; Gamma ray, Porosity, Resistivity, Density, P-wave.

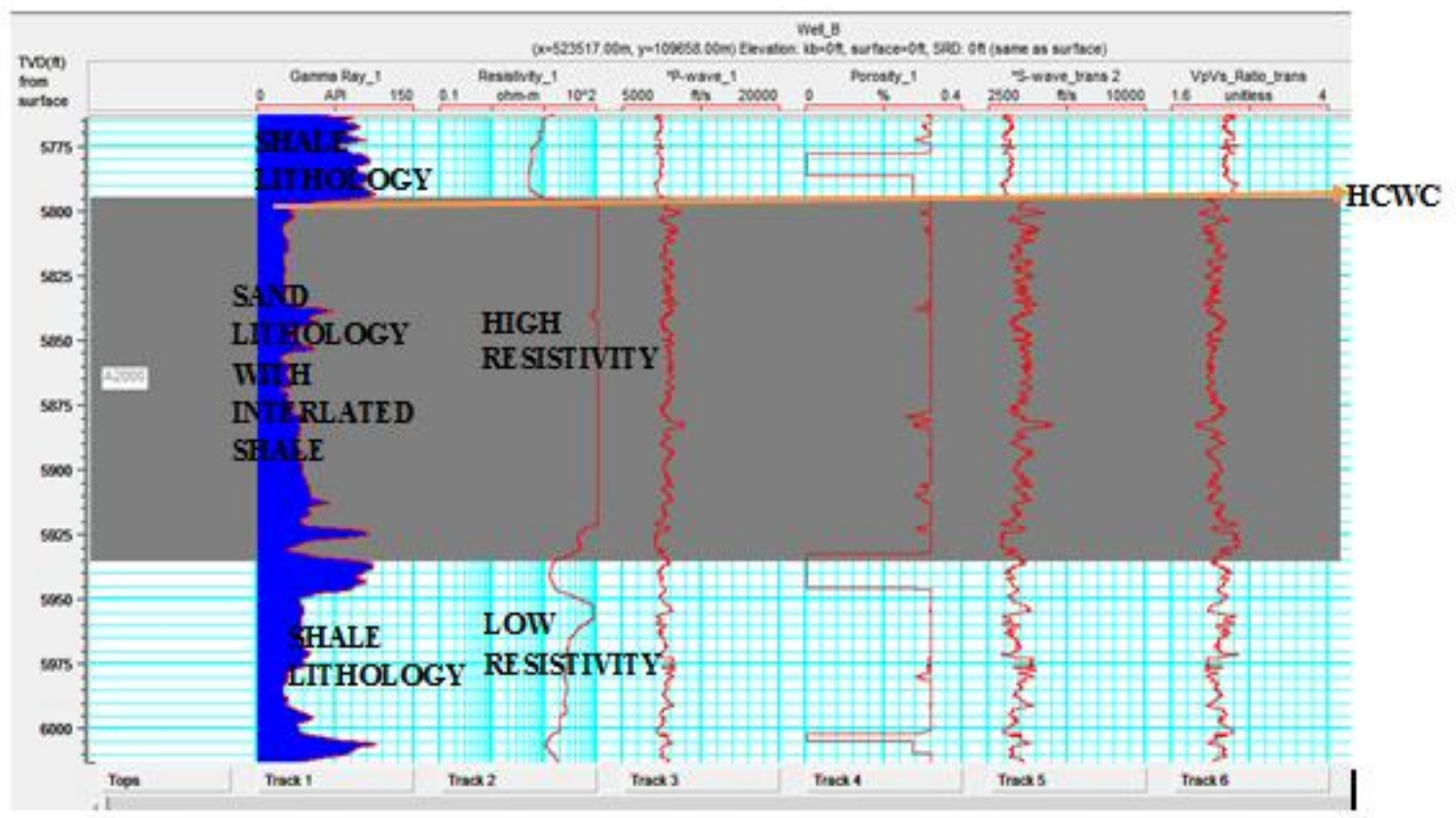

Figure 6: Well B and suite of Logs used in the analysis: Gamma ray, Porosity, Resistivity, density, P-wave 


\subsection{Well-Log Rock Attribute Estimation}

In this stage, rock attributes were estimated from the input log data using rock-physics algorithms created in HAMPSON RUSSELL eLOG tool. Figure 7 shows the tool used in extracting rock attributes from input rock properties. These attributes include shear wave velocity from Castagna's equation, $\mathrm{Vp} / \mathrm{Vs}$ ratio, porosity and acoustic impedance. Figures 8 and 9 show the computed attributes.

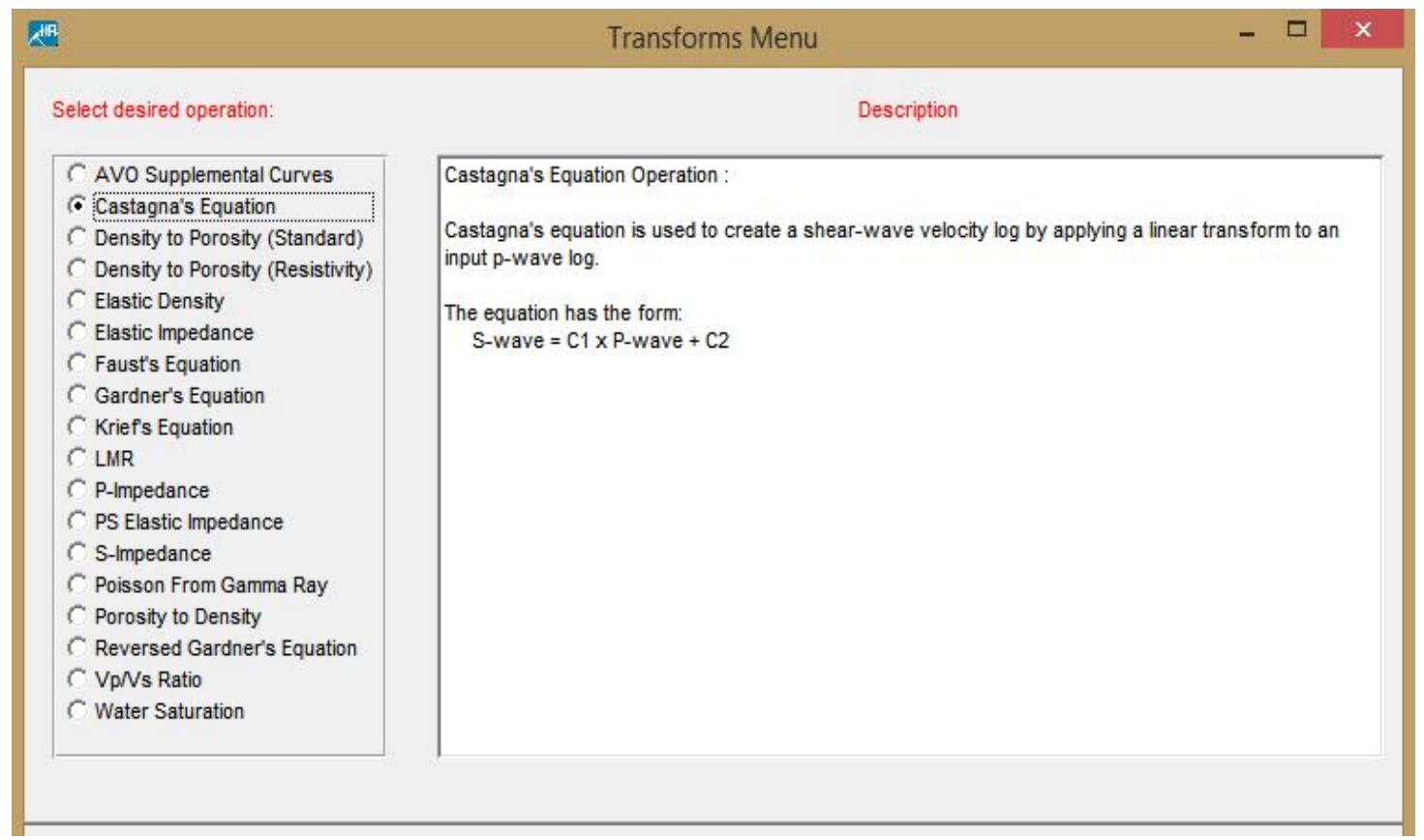

Figure 7: eLog tool used in generating rock attributes from input log data.

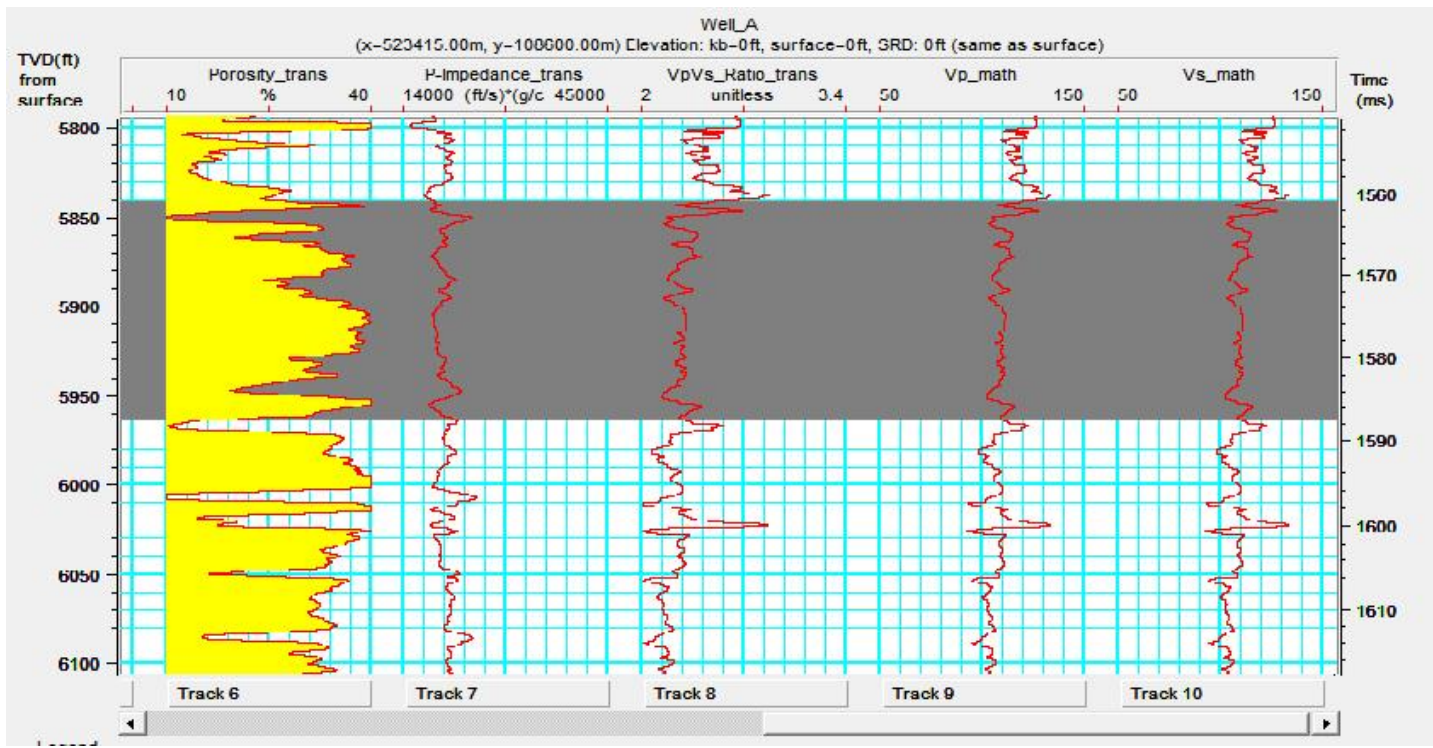

Figure 8: Suite of logs for WELL A showing computed porosity, $V_{\mathrm{P}} / \mathrm{V}_{\mathrm{S}}$ ratio, $\mathrm{P}$-Impedance and $\mathrm{Vp}$ and $\mathrm{Vs}$ logs 


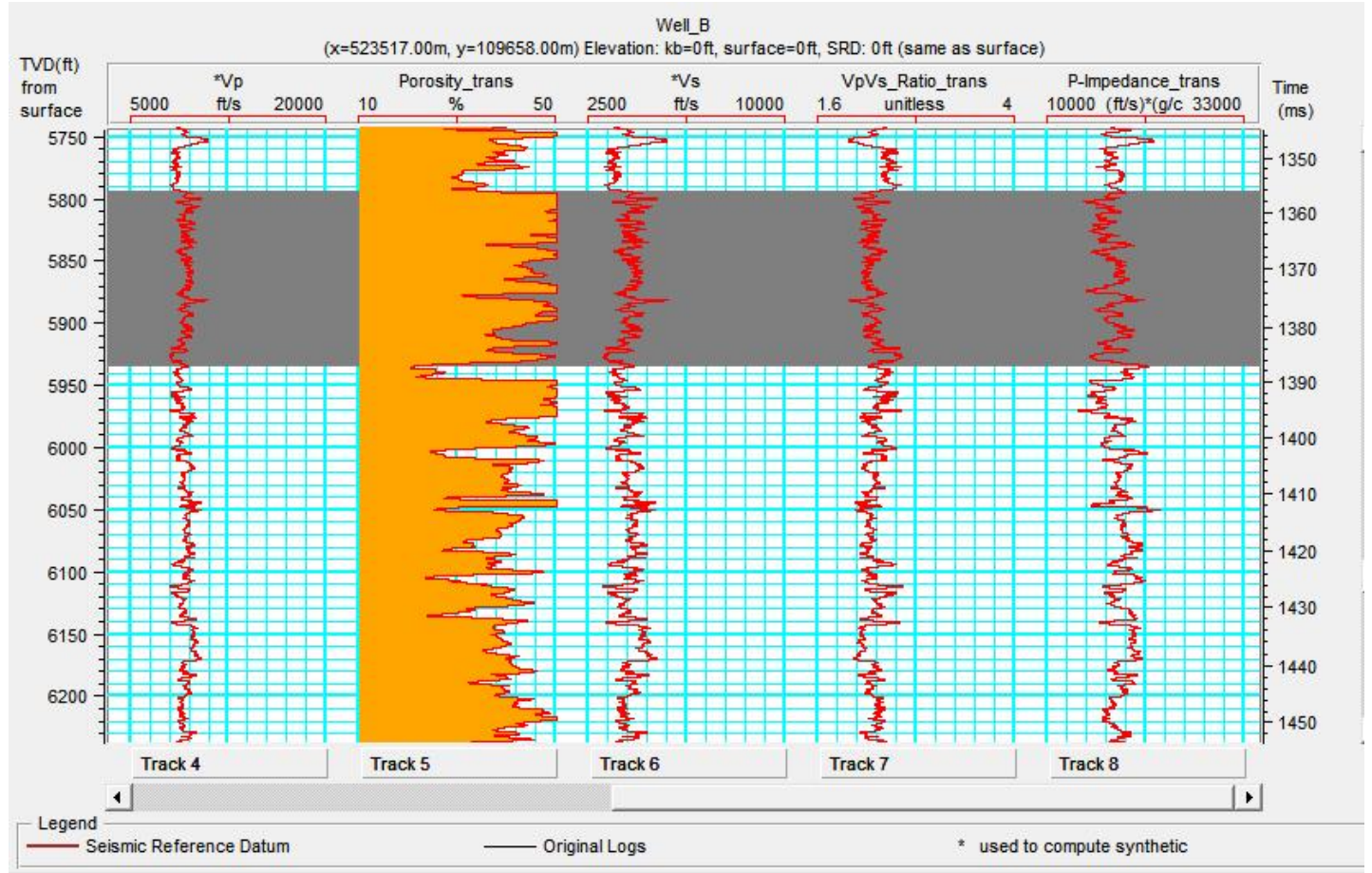

Figure 9: Suite of logs for WELL B showing computed, $V_{s}, V_{\mathrm{P}} / \mathrm{V}_{\mathrm{S}}$ ratio, P-Impedance, and porosity logs.

Acoustic impedance is the product of $p$-wave velocity and density.

$V_{p}$ and $V_{s}$ are computed using the following formula:

$\mathrm{V}_{\mathrm{p}}=1 / \Delta \mathrm{t}_{\mathrm{c}}{ }^{*} 304800(\mathrm{~m} / \mathrm{s})$

$V_{s}=1 / \Delta t_{s}^{*} 304800(\mathrm{~m} / \mathrm{s})$

Where Compressional sonic $\Delta \mathrm{t}_{\mathrm{c}}=1 / \mathrm{V}_{\mathrm{p}}(\mu \mathrm{s} / \mathrm{ft})$ and Shear sonic $\Delta \mathrm{t}_{\mathrm{s}}=1 / \mathrm{V}_{\mathrm{s}}(\mu \mathrm{s} / \mathrm{ft})$
The Shear wave velocity $\left(\mathrm{V}_{\mathrm{s}}\right)$ was computed from the compressional wave velocity using the Castagna and Greenberg's (1993) relations for sand and shale beds as shown in equation 2.

$$
\begin{aligned}
& V s=(0.80416 \mathrm{Vp})-0.85588 \text { (For Shale Beds) } \\
& V s=(0.76969 \mathrm{Vp})-0.86735 \text { (For Sand beds) }
\end{aligned}
$$

\begin{tabular}{|c|c|c|c|c|c|}
\hline & & & & & \\
\hline Fluid Density & $\rho_{f}$ & 1.09000 & grams/cc & Default Brine & - \\
\hline Matrix Density & $\rho_{m a}$ & 2.65000 & grams/cc & Default Sandstone & - \\
\hline
\end{tabular}

Porosity was calculated as shown in equation 4.3 below

Porosity Calculation:

$$
\phi=\frac{\rho_{m a}-\rho_{o b s}}{\rho_{m a}-\rho_{f}}
$$

$\rho_{o b s}$ is the log density

\subsection{Crossplot Analysis}

Crossplots of the elastic properties based on the log measurements for each well were evaluated to better define the relationship between elastic parameters and rock properties, such as lithology and fluid.

The crossplots carried out include the following:

\subsubsection{Vp versus $\mathrm{Vs}$}

The cross plot of shear wave velocity against compressional wave velocity showed a linear trends. Transit time decreases with increasing depths. Compressional wave velocity is greater than shear wave velocity in the study area (figures 10 and 11). This plot does not show fluid contacts but however shows the linear relationship between $V p$ and $V s$. 


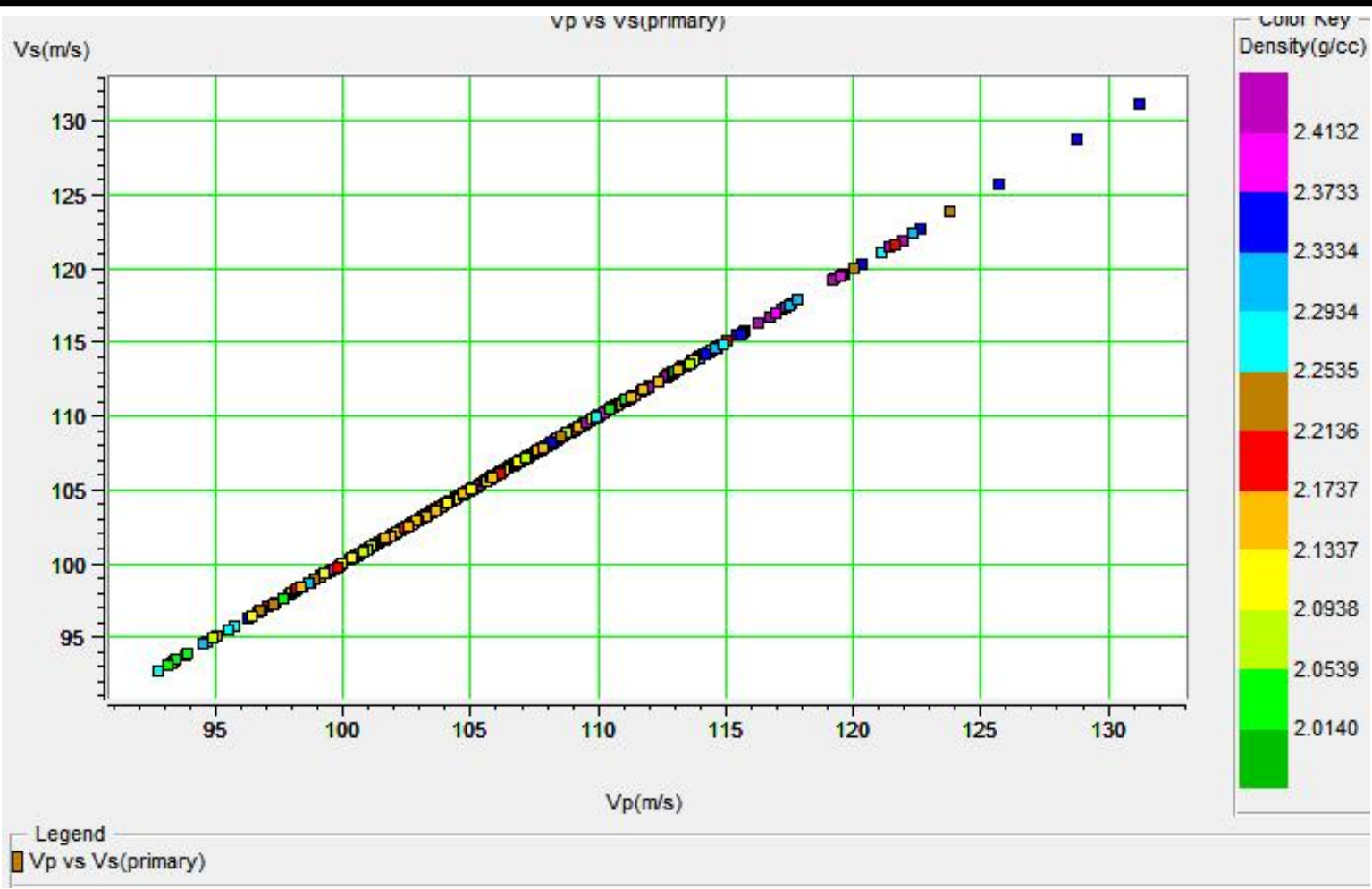

Figure 10: Shear Wave Velocity (Vs) Vs Compressional Wave Velocity (Vp) for Well A

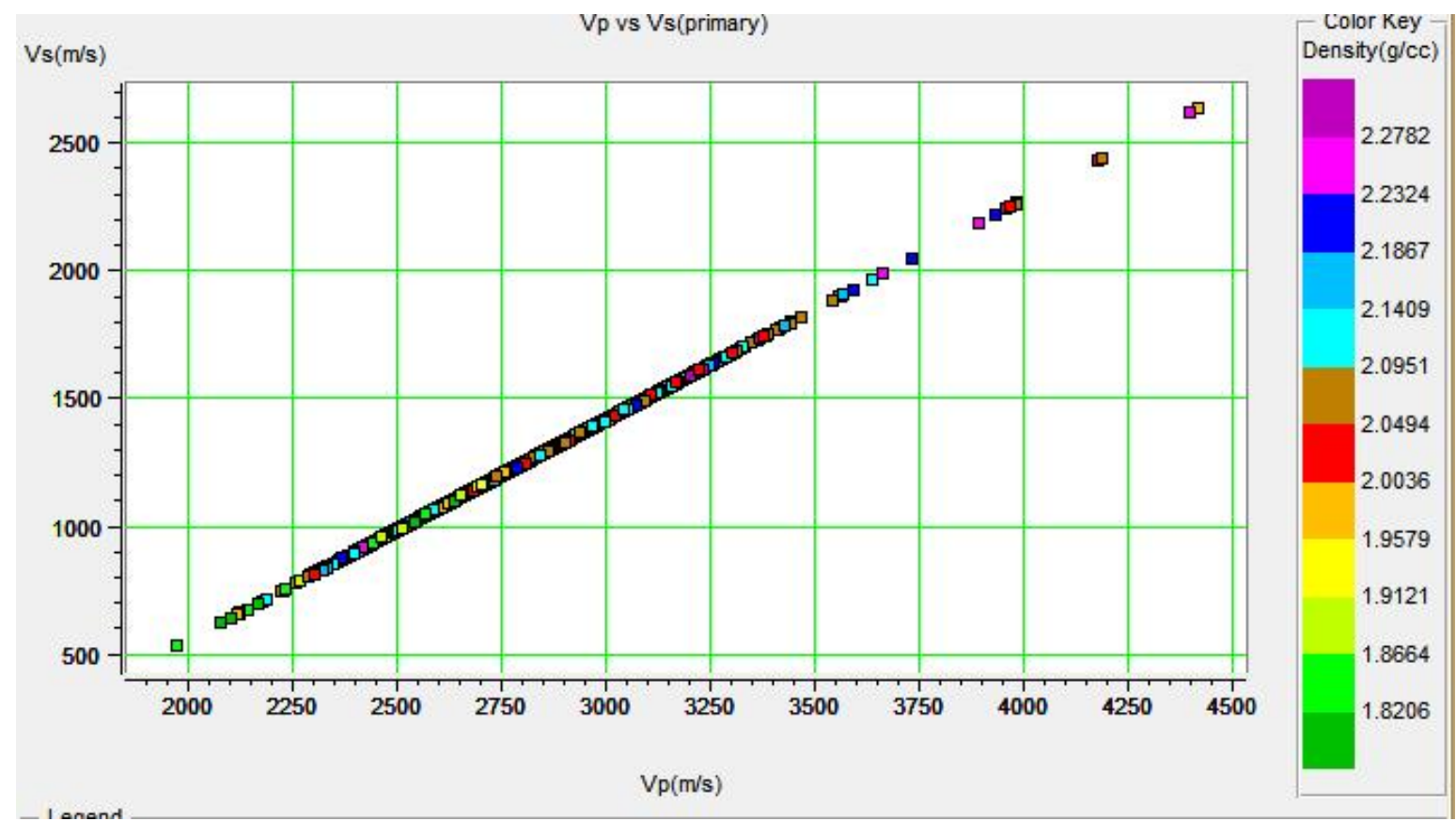

Figure 11: Shear Wave Velocity (Vs) Vs Compressional Wave Velocity (Vp) for Well B

\subsection{2 $V_{\mathrm{P}} / \mathrm{V}_{\mathrm{S}}$ ratio vs Acoustic Impedance (P-Impedance)}

The cross plot of $V_{p} / V_{s}$ ratio against Acoustic impedance $\left(Z_{p}\right)$ (Figures 12 and 13 for Well $A$ and $B$ respectively), distinguishes the $A 2$ reservoir sands into three zones namely; hydrocarbon zone (Green ellipse), brine zone (red ellipse) and shale zone (purple ellipse). This crossplot show better fluid as well as lithology discrimination, indicating that $\mathrm{Vp} / \mathrm{Vs}$ versus acoustic impedance attribute will better describe the reservoir conditions in terms of lithology and fluid content than $\mathrm{Vp}$ versus Vs. 


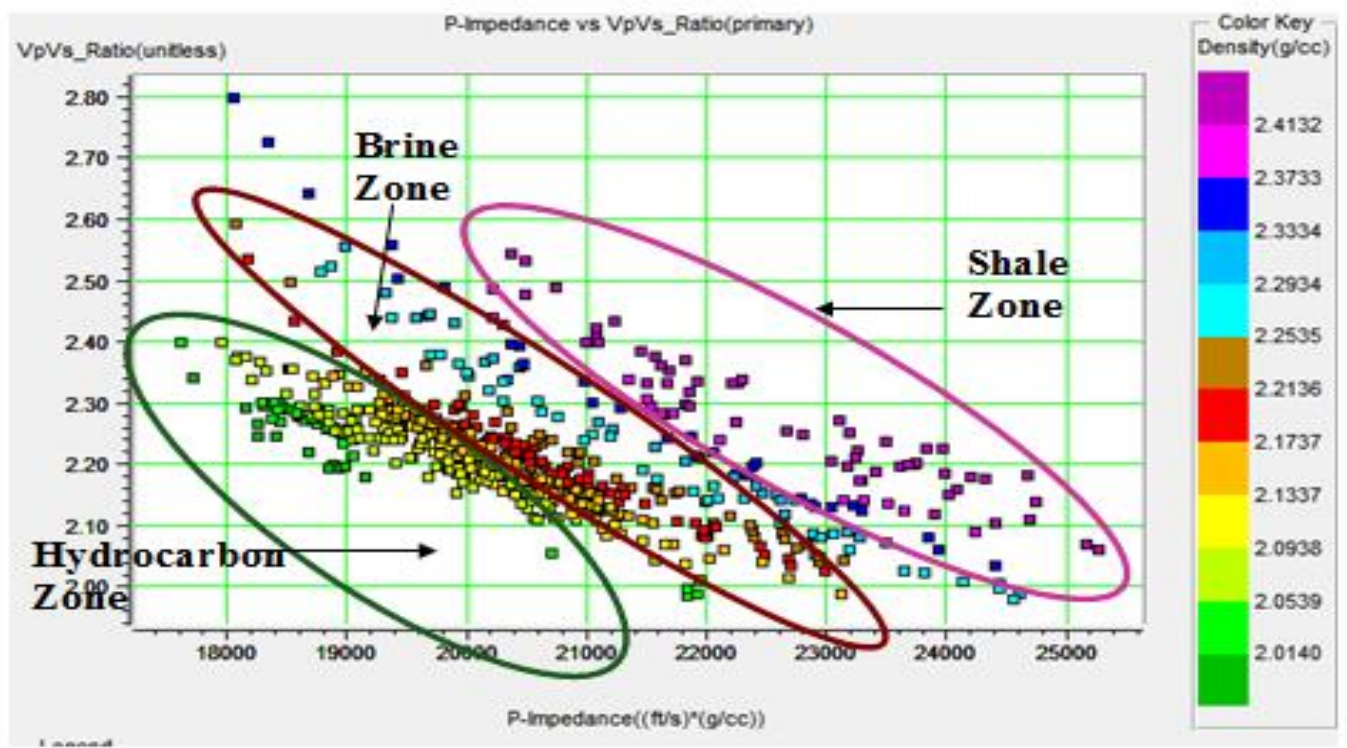

Figure 12: Crossplot of Vp/Vs ratio vs. Acoustic impedance

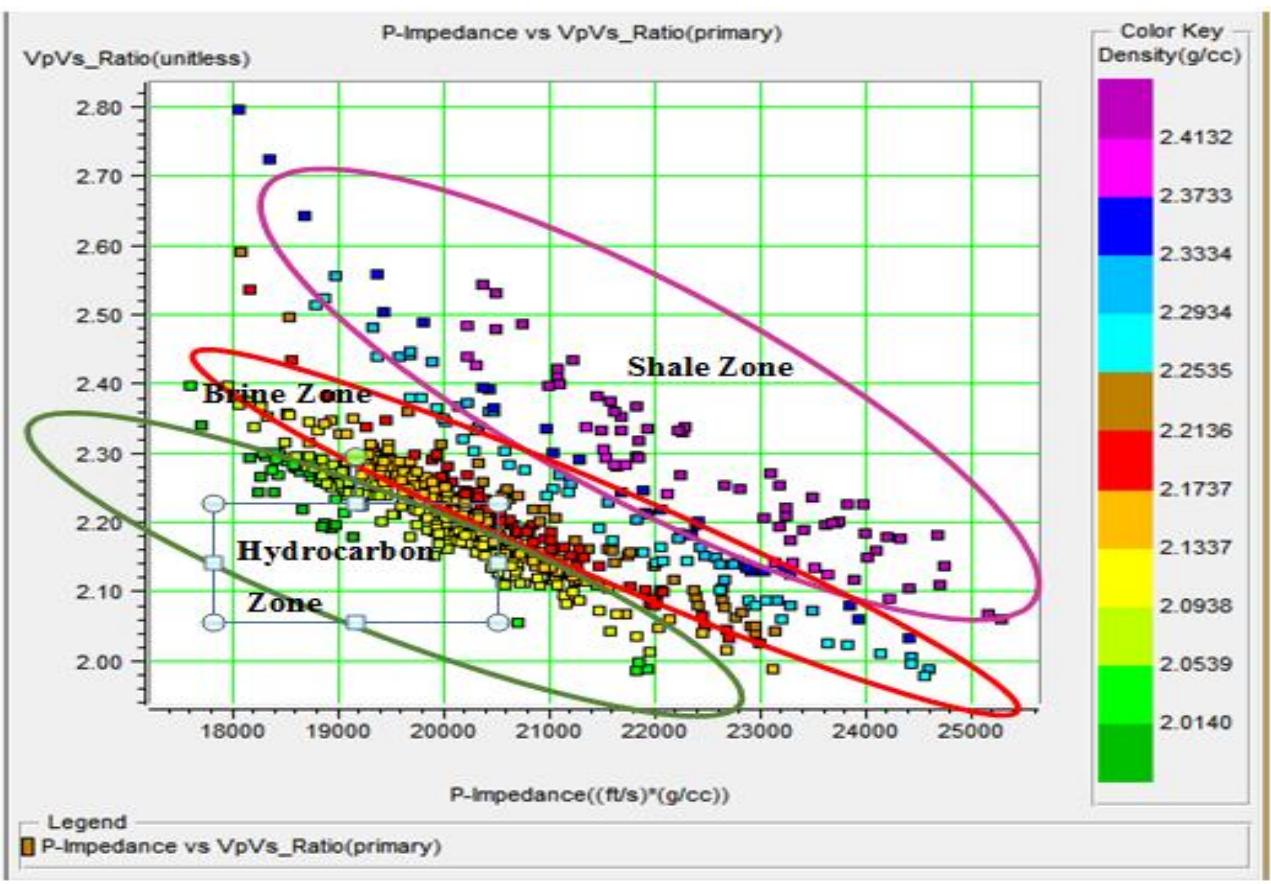

Figure 13: Crossplot of Vp/Vs ratio vs. Acoustic impedance

\subsubsection{Cross plots of $\mathrm{Vp} / \mathrm{Vs}$ ratio Versus Porosity} Crossplot of $\mathrm{Vp} / \mathrm{Vs}$ against Porosity distinguishes the $\mathrm{A} 2$ sand into four zones (Figure 14 and 15 for Well $A$ and $B$ respectively), inferred to be shale (purple), brine (blue), oil (red) and gas (green). The lowest values of $\mathrm{Vp} / \mathrm{Vs}$ and Porosity associated with hydrocarbons are validated by low bulk density as observed from the color code. The plot also indicates that both $\mathrm{Vp} / \mathrm{Vs}$ and porosity, show good discrimination in terms of fluid content. 


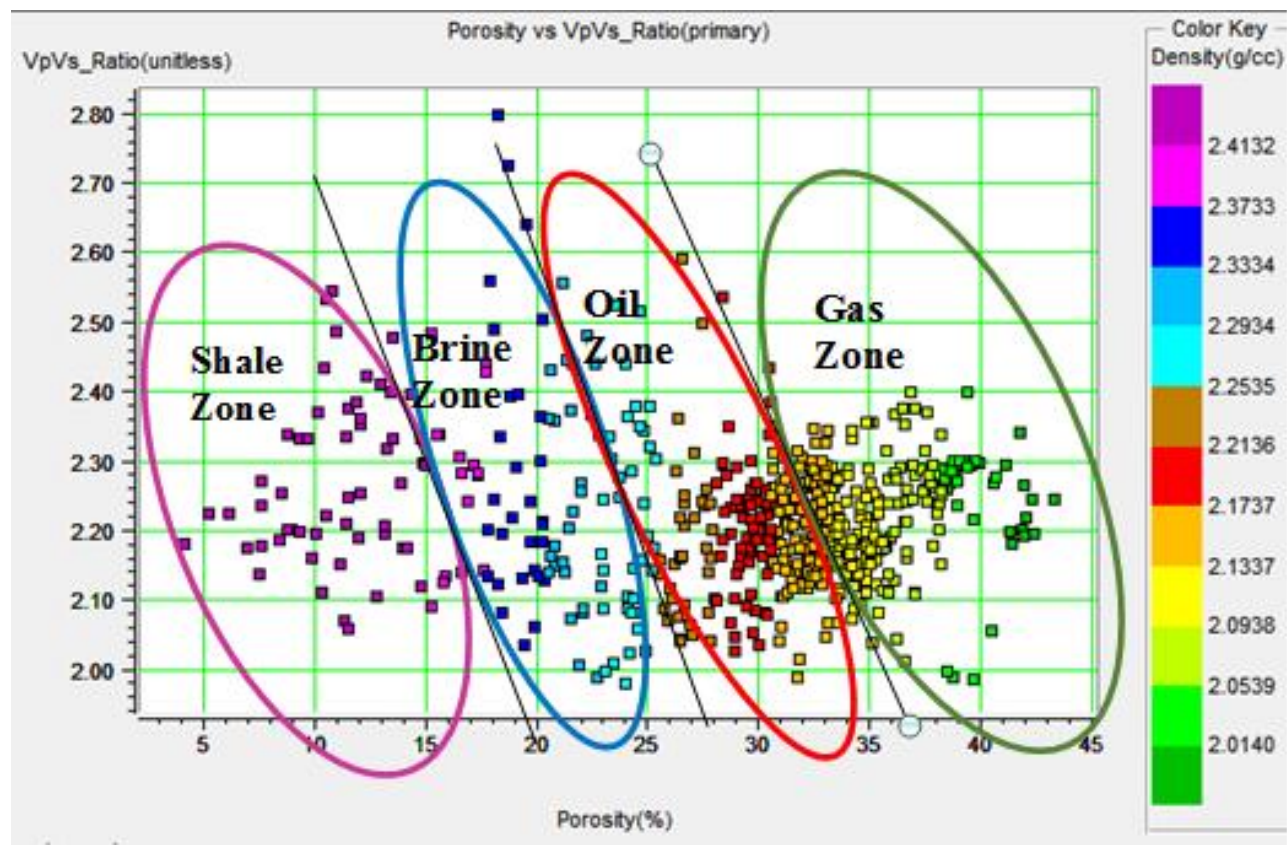

Figure 14: Crossplot of $\mathrm{Vp} / \mathrm{Vs}$ versus Porosity for Well $\mathrm{A}$

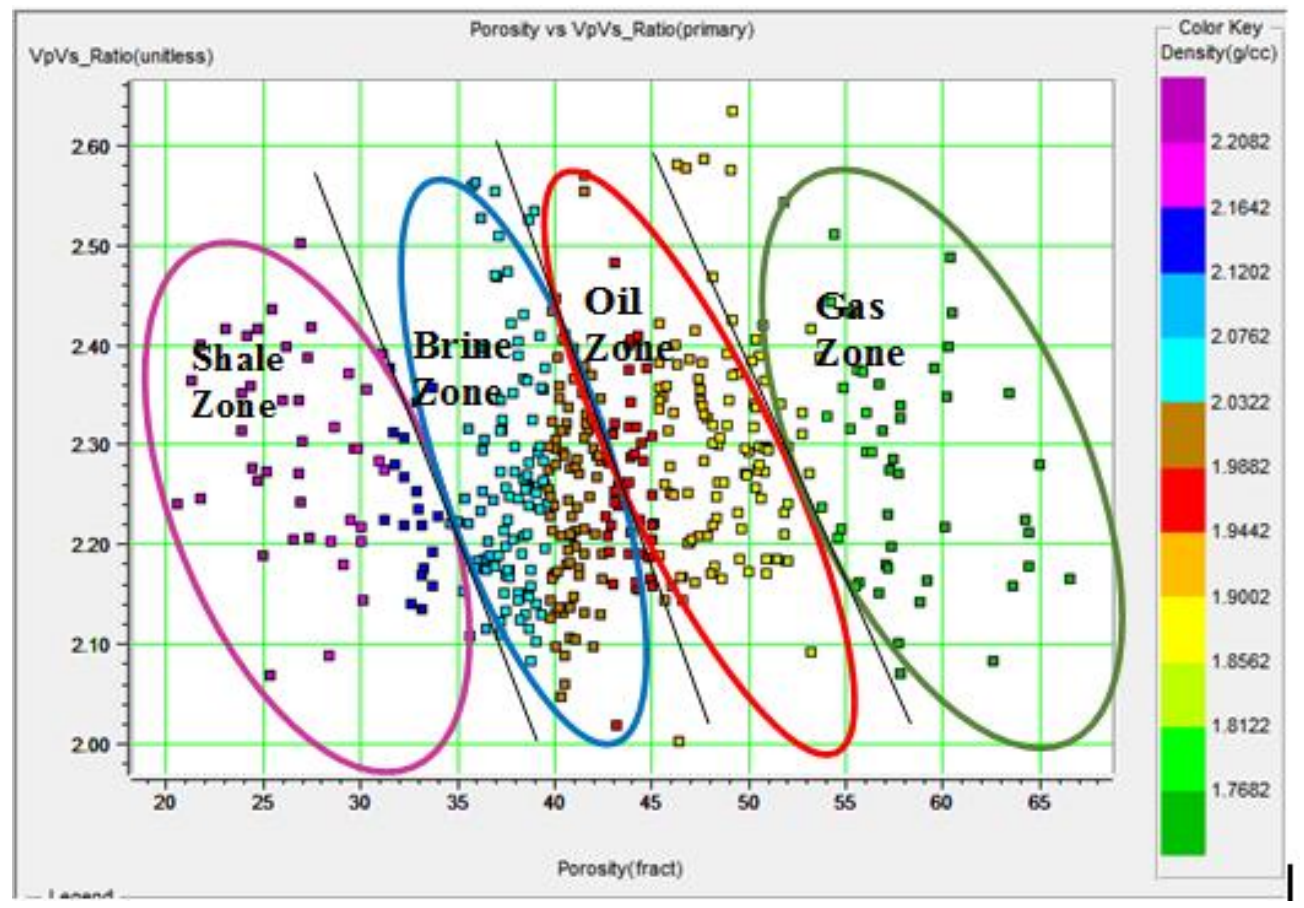

Figure 15: Crossplot of $\mathrm{Vp} / \mathrm{Vs}$ versus Porosity for Well B

\subsubsection{Crossplot of VpVs ratio Versus Density}

Crossplot of VpVs ratio against density distinguishes the A2 sand into four zones (Figure 16 and 17 for Well $A$ and $B$ respectively), inferred to be gas (green), oil (red), brine (blue) and shale (purple). The lowest values of
$\mathrm{Vp} / \mathrm{Vs}$ and density associated with hydrocarbons are validated by low bulk density as observed from the color codes. The plot also indicates that both $\mathrm{Vp} / \mathrm{Vs}$ and density, show good discrimination in terms of fluid content. 


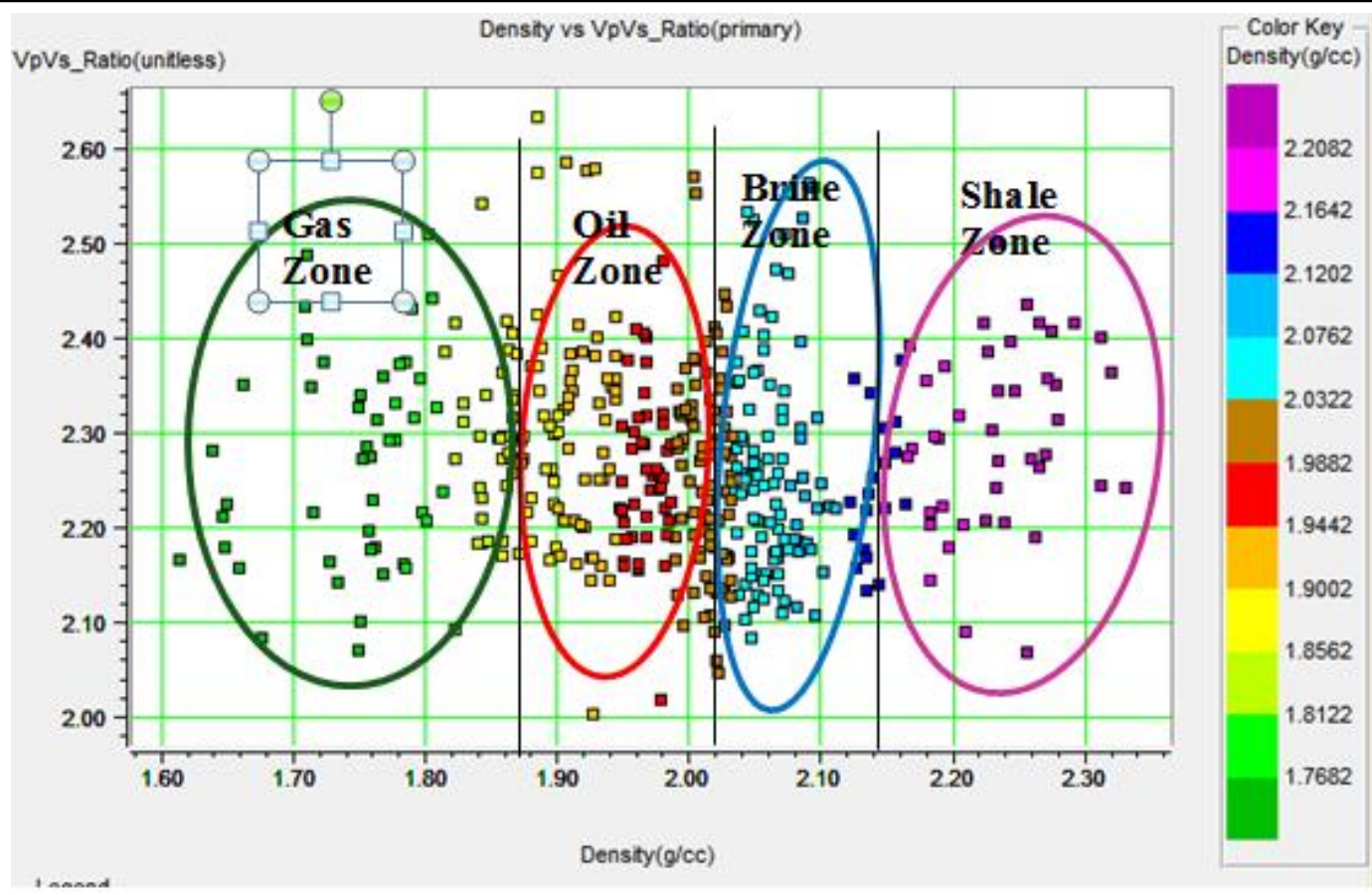

Figure 16: Crossplot of Vp/Vs versus density for Well A

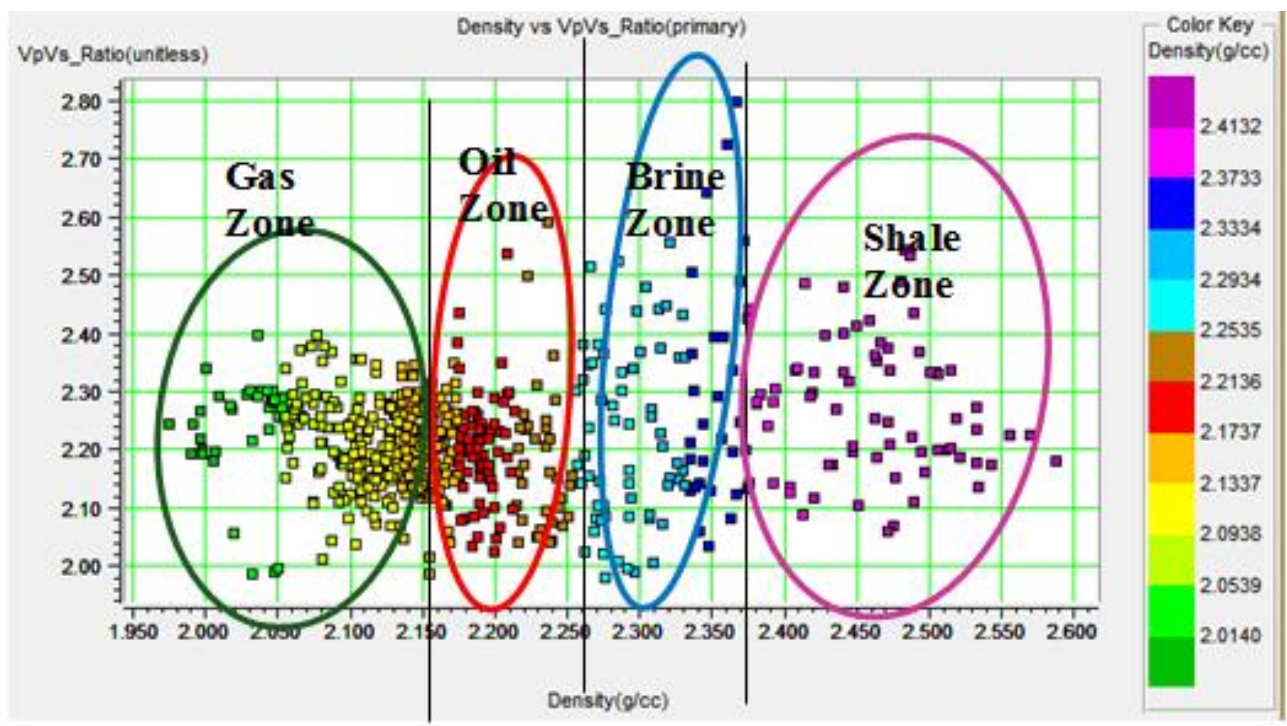

Figure 17: Crossplot of Vp/Vs versus Density for Well B

\subsubsection{Crossplot of Vp ratio Versus Density Colour- coded to Gamma Ray}

The Crossplot of $\mathrm{Vp}$ ratio Versus Density Colour-coded to Gamma Ray differentiates the reservoir based on lithology to sand, shale and shaly sand.

Within the target zone (A2), density is also a good lithological indicator, with densities lower than 2.2 $\mathrm{cc} / \mathrm{g}$ and $1.9 \mathrm{cc} / \mathrm{g}$ (for well $\mathrm{A}$ and $\mathrm{B}$ respectively) indicating sands, and higher values corresponding to shaly sands and shales (Figure 18 and 19 respectively for Well A\& B). Note how P-wave velocity values overlap for sands and shales within the target interval. 


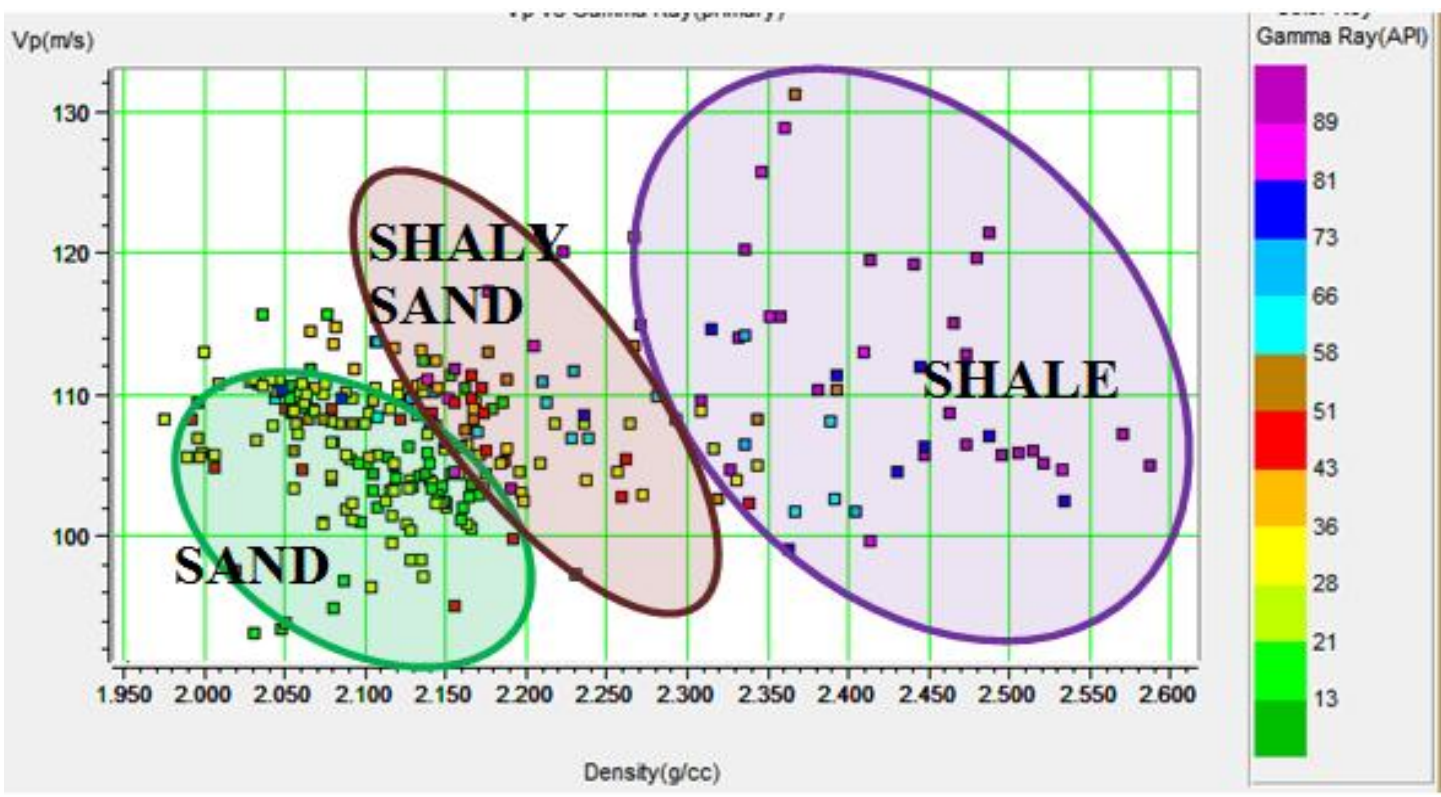

Figure 18: Cross plot of $\mathrm{P}$-wave velocity versus density for Well $\mathrm{A}$ for reservoir A2. Note that there appears to be a separation between sand and shaly sand at $2.2 \mathrm{cc} / \mathrm{g}$. Note how P-wave velocity values overlap for sands and shales within the target interval.

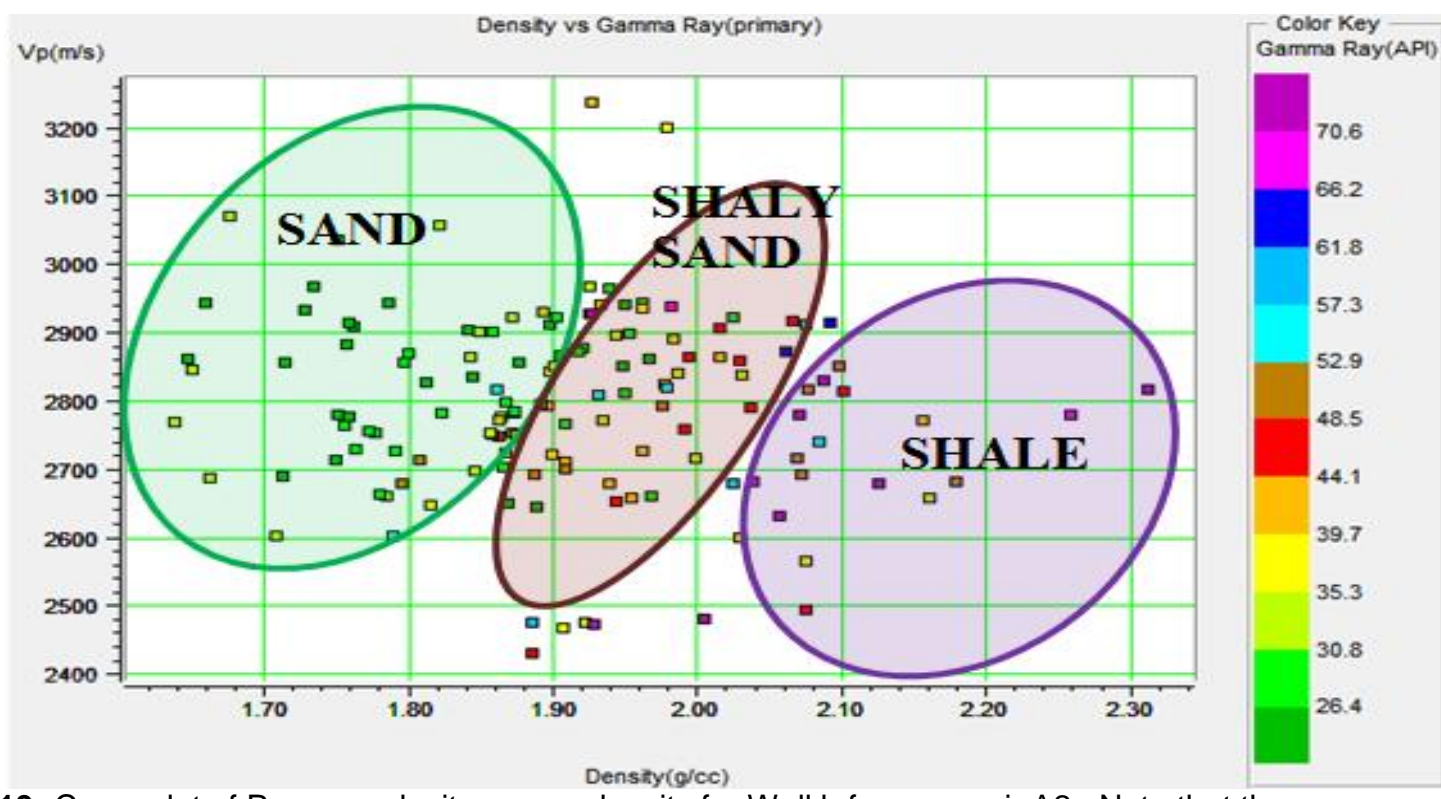

Figure 19: Cross plot of $\mathrm{P}$-wave velocity versus density for Well $\mathrm{b}$ for reservoir $\mathrm{A} 2$. Note that there appears to be a separation between sand and shaly sand at $1.9 \mathrm{cc} / \mathrm{g}$. Note how $P$-wave velocity values overlap for sands and shales within the target interval.

\section{CONCLUSION}

Rock attributes derived from well logs were analyzed in the cross plot domain to describe and characterize the reservoir in terms of fluid type present and lithology. $\mathrm{V}_{\mathrm{p}} / \mathrm{V}_{\mathrm{s}}$ cross plot with other attributes is a good tool to identify fluid nature of a reservoir. It has been tested in this work in an Onshore Niger Delta field with different fluid types (oil, gas and water).

The rock properties and attributes were cross plotted for the primary purpose of investigating their and $V_{s}$ logs were derived from the inverse of interval transit times of sonic and dipole shear logs respectively. $\mathrm{V}_{\mathrm{p}} / \mathrm{V}_{\mathrm{s}}$ ratio, acoustic impedance and porosity were derived from $V_{p}, V_{s}$ and density logs using appropriate relations. The identified depth of reservoir of interest (A2) for Well A and B ranges from $5842 \mathrm{ft}$ to $5964 \mathrm{ft}$ and $5795 \mathrm{ft}$ to $5936 \mathrm{ft}$ respectively. The properties cross plotted comprise $\mathrm{V}_{\mathrm{p}} v s \mathrm{~V}_{\mathrm{s}}, \mathrm{V}_{\mathrm{p}} / \mathrm{V}_{\mathrm{s}}$ ratio $v s \mathrm{l}_{\mathrm{p}}, \mathrm{V}_{\mathrm{p}} / \mathrm{V}_{\mathrm{s}} \mathrm{vs}$. Porosity, $V_{p} / V_{s} v s$ Density and $V_{p} v s$ Density. $V_{p} v s$ Density cross plot revealed that the reservoir consists of sand lithology with intercalated shale. $V_{p} v s V_{s}$ shows a 
reservoir. $V_{p} / V_{s}$ ratio $v s l_{p}$ distinguish $A 2$ into hydrocarbon, brine and shale zones. $\mathrm{V}_{\mathrm{p}} / \mathrm{V}_{\mathrm{s}}$ ratio $v s$ density and porosity crossplots distinguishes the A2 into gas, oil, brine and shale zones. The Acoustic impedance and $V_{p} / V_{s}$ attributes were found to be most robust in lithology and fluid discrimination within the reservoir in the cross plot analysis.

This technique can also be effectively used as a reservoir anomaly tool to check the behavior of the reservoir in the presence of fluids and artifacts. It can also be used as a QC tool on the reliability of well log data.

\section{ACKNOWLEDGEMENT}

I wish to thank Shell Petroleum Development Company, Nigeria for providing the data used for this work.

\section{REFERENCES}

AAPG Wiki http://wiki.aapg.org/Fluid contacts

Allen, J. R. L., 1965. Late Quaternary Niger Delta and Adjacent Areas: Sedimentary Environments and Lithofacies: Bull. AAPG., 48, P 547-600.

Banik, N., Adam, K and Kaseeh, K., 2010. Young's modulus from point-receiver surface seismic data, SEG Expanded Abstracts 29, 2794-2798.

Bradley, H. B., ed., 1987. Petroleum Engineering Handbook: Richardson, TX, Society of Petroleum Engineers.

Beka, F. T and Oti, M. N., 1995. The distal offshore Niger Delta: frontier prospects of a mature petroleum province, in, Oti, M.N., and Postma, G., eds., Geology of Deltas: Rotterdam, A.A. Balkema, p. 237-241.

Burianyk, M., 2000. Amplitude-vs-offset and seismic rock property analysis: A primer: The Canadian Society of Exploration Geophysicist Recorder, $11,1-14$.

Burke, K. C. B., DessaLvagie, T. F. J and Whiteman, A. J., 1971. The opening of the Gulf of Guinea and the Geological History of the Benue Depression and Niger-Delta: Nature Phys. Sci., 233, (38): 51-55.

Castagna, J. P and Swan, H. W., 1997, Principle of AVO cross plotting: The Leading Edge, 04, 337 342.

Chopra, S., Castagna, J and Portniaguine, O., 2006. Thin-bed reflectivity inversion: The Canadian Society of Exploration Geophysicist Recorder, 01, 19-22.

Dabagh, H., Hazim and Alkhafaf, S., 2011. Comparison of $k \rho$ and $\lambda \rho$ in clastic rocks: A test on two wells with different reservoir-quality stacked sands from West Africa, The Leading Edge 30, 986994.
Dewar, J., 2001. Rock physics for the rest of us - An informal discussion: The Canadian Society of Exploration Geophysicist Recorder, 5, 43 - 49.

Doust, H and Omatsola, E., 1990, Niger Delta, in, Edwards, J. D., and Santogrossi, P.A., eds., Divergent/passive Margin Basins, AAPG Memoir 48: Tulsa, American Association of Petroleum Geologists, p. 239-248.

Eastwood, R. L and Castagna, J. P., 1983. Bases for interpretation of (VP/VS) ratios in complex lithologies. Soc. Prof. Well Log analysts 24th Annual logging Symposium.

Edwards, J. D and Santogrossi, P. A., 1990. Summary and conclusions, in, Edwards, J.D., and Santogrossi, P.A., eds., Divergent/passive Margin Basins, AAPG Memoir 48: Tulsa, American Association of Petroleum Geologists, P. 239-248.

Ejedawe, J. E., 1981. Patterns of incidence of oil reserves in Niger Delta Basin: American Association of Petroleum Geologists, v. 65, p.1574-1585.

Evamy, B. D., Haremboure, J., Kamerling, P., Knaap, W. A., Molloy, F. A and Rowlands, P. H., 1978. Hydrocarbon habitat of Tertiary Niger Delta: American Association of Petroleum Geologists Bulletin, v. 62, p. 277-298.

Greenberg, M. L and Castagna, J. P., 1992, Shear-wave velocity estimation in porous rocks: theoretical formulation, preliminary verification and applications. Geophysical Prospecting, 40, 195209.

Greenberg, M. L and Castagna, J. P., 1993. Shear-Wear Velocity Estimation in porous Rocks. Theoretical formulation, Preliminary verification and applications. Geophys. Prosp., 40, 195-209.

Hamada, G. M., 2004. Reservoir Fluids Identification Using Vp/Vs Ratio: Oil \& Gas Science and Technology - Rev. IFP, 59, (2004), (6): 649654.

Henry, S., 2006. Undestanding seismic amplitudes: www.searchanddiscovery.net

Kuster, G. T and Toksöz, M. N., 1974. Velocity and attenuation of seismic waves in two media: Part I. Theoretical considerations: Geophysics, v. 39, p. 587-606.

Murat, R. C., 1972. Stratigraphy and Paleogeography of the cretaceous and Lower Tertiary in Southern Nigeria. in T.F.G. Dessauvagie and A.J. Whitman eds., African Geology. University of Ibadan.P.251 -266.

Omudu, L. M and Ebeniro, J. O., 2005. Cross plot of rock properties for fluid discrimination, using 
well data in offshore Niger Delta: Nigerian Journal of Physics, vol. 17, 16-20.

Orife, J. M and Avbovbo, A. A., 1982. Stratigraphic and unconformity traps in the Nigeria Delta: AAPG Bulletin, 66, (2): 251-262.

Pickett, G., 1963. Acoustic Character Logs and their applications in formation evaluation. J. Petr. Tech., $659-667$.

Rafavich, F., Kendall, C. H., St. C and Todd, T. P., 1984. The relationship between acoustic properties and the petrographic character of carbonate rock: Geophysics, 49, 1622 - 1636.

Reijers, T. J. A., Petter, S. W and Nwajide, C. S., 1996. The Niger Delta basin: iflReijers, T.J.A., ed.,: Selected Chapter on Geology: SPDC Wa.:LP1O3-118

Sheriff, R. E., 2002. Encyclopedic dictionary of Applied Geophysics, 4th edition: Society of Exploration Geophysicists, Tulsa, Oklahoma.

Short, K. C and Stauble, A. J., 1965. Outline of geology of Niger Delta: American Association of Petroleum Geologists Bulletin, v. 51, p. 76 1779.

Stacher, P., 1995. Present understanding of the Niger Delta hydrocarbon habitat, in, Oti, M.N., and Postma, G., eds., Geology of Deltas: Rotterdam, A.A. Balkema, p. 257-267.

Tamunobereton-ari, I., Omubo-Pepple, V. B and Uko, E. D., 2010. The Influence of Lithology and Depth on Acoustic Velocities in South-East Niger Delta, Nigeria. American Journal of Scientific and Industrial Research, 1, (2): $279-292$.

Tamunobereton-ari, I., Omubo-Pepple, V. B and Uko, E. D., 2011. Determination of the Variability of Seismic velocity with Lithology in the South-Western part of the Niger Delta Basin of Nigeria using well logs. Journal of Basic and Applied Scientific Research 1, (7): 700 - 705.

Tuttle, M. L. W., Charpentier, R. R and Brownfield, M. E., 1999. The Niger Delta petroleum system: Niger Delta province, Cameroon, and Equatorial Guinea, Africa: http://greenwood.cr.us gs. gov/energy/ Won dEnergy/O F99-5 0H/ChapterA.htm\#TOP

Veeken, P. C. H and Rauch, M., 2006. AVO attribute analysis and seismic reservoir characterization. First break. 24: 41-52.

Wang, Z., 2000. Velocity relationships in granular rocks, in Z. Wang and N. Amos, eds., Seismic and acoustic velocities in reservoir rocks, vol. 3: Geophysics Reprint series, 377- 1383.

Weber, K. J., 1971. Sedimentological aspects of Oil fields in the Niger-Delta: Geol. criMijnb., 50, (3): 559-576.
Weber, K. J and Dakouru, E. M., 1975. Petroleum geology of the Niger Delta: Proceedings of the Ninth World Petroleum Congress, volume 2, Geology: London, Applied Science Publishers, Ltd., p. 210-221.

Whiteman, A., 1982. Nigeria: Its Petroleum Geology, Resources and Potential: London, Graham and Trotman, 394.

Xu, S and White, R., 1996. A physical model for shear wave velocity prediction: Geophysical Prospecting, 44, 687-717. 